\title{
ALTERNATIVE RELIGION IN PRETORIA New Forms of Christianity Part I $\mathbf{I}^{1}$
}

\author{
Michel Clasquin \\ University of South Africa
}

\begin{abstract}
This article is part of a larger research project on patterns of religious pluralism in the city of Pretoria, and is based on field research conducted in in the period 1993. 1995 by the author, Prof JS Krüger and Mr MS (Victor) Molobi. Material extraneous to the main thrust of the project is being published in a series of articles. This article describes the rise of alternative religious forces in Pretoria during the late nineteenth and early twentieth centuries and how these faiths have accommodated to the religious environment of the city. Part I deals with those groups that, while perhaps unorthodox, still base themselves on the Christian tradition and ethos, these being the New Apostolic Church, Latter-Day Saints (Mormons), Adventists and Jehovah's Witnesses. Part II will take a look at a different and new influence, namely those traditions new to the city that base themselves on Eastern thinking.
\end{abstract}

\section{Introduction}

There are a number of religious traditions present in Pretoria that may be seen as constituting a distinct religious bloc. There are great theological differences between them, but there are nevertheless sufficient similarities, sufficient common factors, to enable us to see them as a distinct form of religious expression. Although any one of these churches may not conform to all these factors, as a group they are defined by them. The common factors are as follows:

- American origin

- Origin in the early nineteenth century

- An explicitly Christian-inspired worldview

- A tendency to highlight a particular verse or theme from the Bible and to promote this to a greater extent than would be done with that particular verse or theme in 'mainstream' Christianity

- A tendency to central control of ecclesiastical affairs, even to the point of authoritarianism

- A general conservatism in social and political matters, but not to the extent of religious justification of racism.

The examples of such groups that we shall discuss here are, in alphabetical order, the Jehovah's Witnesses, Mormons (LDS Church) ${ }^{2}$, New Apostolic Church and Seventh Day

1. Part II of this article will be published in a forthcoming edition of Scriptura

2. The 'Mormons' are, of course, officially known as the 'Church of Jesus Christ of Latter-day Saints', a name which does tend to be a bit unwieldy in an article of this size. In our interview, however, their spokespersons indicated that they did not object to 'this little nickname'. The convention we will follow from here is to refer to the organisation as the 'LDS Church' and to its members as 'Mormons'. 
Adventists. It should be stressed that this grouping is one of our devising; as far as we could discover, these churches do not think of themselves as related to each other. At least some of them might disagree with our classification system. Nevertheless, as we shall see, there are good reasons for grouping them in this way.

One other group should be mentioned in this regard, namely Christian Science. It resembles the groups described in this chapter in many respects, but also has factors in common with the Eastern-influenced groups described in Part II of this article. One could almost see it as a 'transitional' or 'intermediate' development between these two groups of nineteenth century traditions, not in strict chronological or developmental terms, but in terms of a shift from one set of religious tendencies to another. To make this clear, we shall discuss. Christian Science in Part II.

\section{Origins}

The first prominent feature of this group of religious traditions concerns their heritage. They all reached Pretoria in the first half of the twentieth century. All but one of them can trace their immediate history as distinct religious organisations to early nineteenth century America.

\section{The New Apostolic Church}

The exception here is the New Apostolic Church, the roots of which go back to Germany ${ }^{3}$, and beyond that to the establishment of the Catholic Apostolic Church in England in 1832. An important innovation made at this time was the establishment, or re-establishment, of the title of Apostle.

That is what is unique about the old church, whereas other churches just talk about Apostles, we actually have them ${ }^{4}$. In the 1830 s many people from various churches were coming together to experience the fulfilment of a promise made in the olden days, that their sons and daughters would see visions and so on, and that they would prophesy. There were people gathering from all different religions looking for lost gifts in the church. And eventually people became prophets. They started prophesying and telling the people what to pray for. And the most important aspect of their prophecy was that they should pray for the reinstatement of the Apostle ministry.

An important text in the re-establishment of the Apostle ministry seems to have been Ephesians 4:11: 'It was he who gave some to be apostles, some to be prophets, some to be evangelists and some to be pastors and teachers ...'. Eventually, a number of Apostles were appointed and given responsibility for different parts of the world. In South Africa, the first Apostle was Carl G Klibbe, who arrived from Germany at the turn of the century. When Klibbe went on a prolonged visit to Europe in the early twenties, the young church was under the care of Bishop GH W Schlaphoff. A power struggle followed on Klibbe's return and after a court battle the church split in two, the Klibbe faction calling itself the Old Apostolic Church and the Schlaphoff group being named the New Apostolic Church, with Bishop Schlaphoff being raised to the rank of Apostle. Both churches survive to this day, with no possibility of reunification in sight. Our impression is that the Old Apostolic Church is

3. The current headquarters are in Zurich, Switzerland.

4. While not wishing to contradict our informant, it should be pointed out that the LDS Church also has officials called Apostles. Whether the functions perforned by these people in the two churches are identical would, however, require a more in-depth study than we were able to perform here. 
currently somewhat more black-dominated than the New Apostolic Church. A black member of the New Apostolic Church explained: 'The Old Apostolic Church is no longer connected to white people, it is now independent, and the white person who started this church was eventually excommunicated.' There does not, however, seem to be much difference between them in terms of theology or organisational structure ${ }^{5}$. In 1992, the New Apostolic Church had 126939 members in South Africa (South African Statistics 1992, section 1.18.)

In Pretoria, the New Apostolic Church was established in 1922 by a lay preacher named JR Kreunen. He was ordained first a sub-deacon and then a deacon in that same year, and his career would culminate in his ordination as Apostle in 1954.

The first church building was completed in 1930. It stands in Pretorius Street in central Pretoria. The regional headquarters is not situated in this church building, however, but in the Gezina congregation. There are currently 13 congregations in Pretoria, divided into five districts and serving 8350 church members. Two Apostles worked in the area in 1988, namely Apostles De Smedt and Marema, '... and each Apostle has two bishops'.

In 1988, the New Apostolic Church in Pretoria celebrated a visit by the movement's Chief Apostle, Richard Fehr, from Switzerland. This prompted the publication of a booklet celebrating the history of the church in Pretoria (New Apostolic Church 1988). Our informant was kind enough to present us with a copy and much of this information was obtained from it.

Charitable action by the New Apostolic Church in Pretoria is largely limited to the church's own members. There is no church-run old age home, but 'our old people are well looked after by the Lord.'

\section{The Adventists}

All the other movements discussed in this chapter have an American history. Seventh Day Adventism, for instance, can be traced back to the remarkable religious career of William Miller, the nineteenth century New England lay preacher. He predicted that the second coming of the Messiah would occur within a year of 21 March 1843. The failure of his predictions to come true, an event known in Adventist history as 'the Great Disappointment', caused the loss of many of his followers, then known as the Millerites. But the movement did not die out. The name 'Seventh Day Adventism' was first adopted in 1860 and the Seventh Day Adventist Church held its founding convention in 1863. Overseas missionary work commenced in 1874. By 1878, a letter was received by the Review and Herald, an official Seventh Day Adventist Church publication, in which a man named J H C Wilson described how he had been converted by reading the literature distributed on the Kimberley diamondfields by an American fortune-seeker named William Hunt. In 1885, Hunt met two South African families who had arrived at conclusions very similar to those of Adventism through personal Bible study. Together, they requested help from the church in the USA and four missionaries arrived in 1887 to found the first Adventist Church in South Africa in Beaconsfield, Kimberley. In 1889 the group joined the world church as the 'South African Conference'. One of our respondents attached great importance to these historical circumstances:

As a South African, I see the Seventh Day Adventist Church as a uniquely South African church, for it started here independently. It wasn't imported from Holland like the Dutch

5. This impression is derived from third-hand information, for despite our best efforts we were unable to arrange an interview with a spokesperson for the Old Apostolic Church. 
Reformed Church or from America like the Baptists. Later, they did join the organisation in America, but I see it as an exceptional South African church that was started right here. A movement founded not by a single person but which started around the world at approximately the same time.

Today, the Seventh Day Adventist Church is distributed in 204 countries and territories. It is widely regarded as '... the hardiest and most active of the groups which trace their beginnings to this period (of William Miller and his millenarian movement)' (World Council of Churches 1973: 57). Today the church, the South African branch of which is based in Bloemfontein, is widely distributed across the country. Its pastors receive their theological training at Helderberg College in Somerset West, in cooperation with Andrews University in the USA. The black and white churches merged in December 1991 and local conferences are in the process of merging.

The first Seventh Day Adventist Church congregation in Pretoria was established in about 1925 as a home church of about eight people. For a while Sabbath services were conducted in the Trades Hall in Skinner Street. In 1930 the group moved into a church building at 395 Schoeman Street, which was later sold when a garage was built next to the church. A bilingual church was built in Van Boeschoten Avenue, next to the Apies River. This church was later sold to the Transvaal Education Department. A new Afrikaans Church was built in Joubert Street in Sunnyside, where a church school (est 1933) is still active today. The English-speaking church members eventually started to worship in the Hamilton School Hall in Visagie street. In 1950 this group was organised as a fully-fledged group by the Conference. Various other congregations were then gradually established in the different suburbs in Pretoria, until today there are 13 congregations. There is very little information available on the establishment of black congregations in Pretoria.

The church is highly active in service organisations - it runs the well known 'Meals on Wheels' organisation, which delivers meals to the aged and infirm. It also has a service centre and the Magnolia Old Age Home established in the city, the abovementioned private primary school of which about $75 \%$ of the pupils belong to the Seventh Day Adventist Church, and owns a share in a private psychiatric hospital, the Vista Clinic in Verwoerdburg. Individual members are also active in Lifeline, a nondenominational telephonic counselling service. This is not unique to the Pretoria branch of the church - our respondent informed us of food distribution programmes in Ethiopia, Somalia and Russia undertaken by Adventists.

There are two church organisations present in Pretoria that can trace their origin back to the Millerite revival; the Seventh Day Adventist Church discussed above, and the Seventh Day Adventist Reform Movement. The Reform Movement was founded in Germany between the two World Wars largely as the result of a dispute about military participation by Adventists. It finally broke away in 1925 and came to South Africa around 1935 (There does appear to have been a branch in Salisbury (Harare) a few years earlier).

The Reform Movement is a small church, with perhaps a thousand members in South Africa, of which fifty belong to the Pretoria congregation. It is also less assertively missionary than the larger Adventist organisation. Interestingly, our respondent mentioned that most of its members are ex-members of the Seventh Day .Adventist church. This, he suggested, is a global trend: 'Wherever there are Adventists, there are Reformed Adventists'. The Reform Movement's church building in Centurion serves members from both Pretoria and Johannesburg. 


\section{The Latter-day Saints (Mormons)}

The LDS Church was founded by Joseph Smith, an American, in 1830. He claimed to have received a new revelation from an angel named Moroni, which he had then translated and published as The Book of Mormon. The LDS Church quickly attracted many followers and was subjected to successive waves of persecution that culminated in the murder of Smith himself. He was succeeded as the movement's leader by Brigham Young. The persecution forced the Mormons to trek ever further westwards until they finally found a home in Salt Lake City, Utah, a city which they founded.

The LDS Church was a missionary organisation from its inception, and the first Mormon presence in South Africa was in Cape Town around the year 1852. In 1992, the official statistical handbook for South Africa tells us that there were 7031 Mormons in South Africa (South African Statistics 1992, section 1.18). Our respondents from the LDS church, however, claimed to have between 22 and 23000 members. It must be kept in mind that the 1992 census figures do not include the then-TBVC states.

Contrary to popular belief, the LDS Church today does not practice or condone polygamy, though there are a few splinter groups in the USA that have continued the practice. According to our informants, the LDS Church was established in Pretoria in about 1936.

The first meeting place was in a hall in Church Street West. There was a café on the corner and above the café was a snooker hall in which the people would actually meet on Sundays. And then they moved away from there to a military building, some place near the main post office. Later they met in sister Lane's home in Esselen Street in Sunnyside, opposite the brewery, and also in sister Kunitz's place in Servaas Street in Pretoria West. In 1961 to 1962 the building in Sunnyside, which is still standing, was built. The Apostle Boyd K Packer was sent to South Africa when the Pretoria chapel was opened in 1962. And he dedicated the chapel.

Since these early days, the Mormons have built another church building in Verwoerdburg, and more recently one in Atteridgeville. LDS membership in Pretoria is estimated at one to two thousand.

The LDS Church maintains welfare programmes both within and without the church. This is largely under the control of the female members. Among the programmes the church has started in Pretoria are classes in literacy, hygiene and homemaking skills. There are no formal old-age homes, and in fact the church places a high value on its members' selfreliance. However, internal structures in the church under the direction of the bishop or branch president help members in need.

\section{Jehovah's Witnesses}

The Jehovah's Witnesses are perhaps the best-known of all these groups, probably because of the long time they have been established in South Africa and Pretoria, and because of their policy of 'witnessing' activities (hence the name). Witnessing entails going from door to door, asking the inhabitants whether they might come in and discuss their religion and leaving behind a religious tract and a blessing.

It started a little later than the other churches discussed in this chapter: the group was formally founded in 1881 by Charles Taze Russell, in Pennsylvania, the American state that owed its very existence to religious nonconformism. He was succeeded as President of the movement by JF Rutherford, NH Knorr and FW Franz. The movement grew rapidly and '(by 1888 ) its representatives were active in China, India, Turkey, Haiti and Africa' (Davies, in 
Hewat 1967:13). The movement was at first officially known as 'The Zion's Watch Tower Tract society' and later as the 'Watch Tower Bible and Tract Society'. The name 'Jehovah's Witnesses' was first adopted in 1931. They claim an international membership of over three million and their magazine, the Watch Tower, is now available in over a hundred languages.

They seem to have first entered South Africa around 1908, when 'Joseph Booth, an Australian fundamentalist ... introduced a Nyasa (Malawian) migrant worker, Elliot Kamwana, to Studies in the Scriptures ...'(Hodges1985: 6-7). By 1985, there were a claimed 31744 publishers (Jehovah's Witness terminology for a full member of the organisation who is engaged in 'witnessing' activities) in South Africa, an increase of $10 \%$ over 1982 (Hodges1985: 15). It is not known whether this number included the then 'independent homelands', but this is quite likely, since none of these are included in the Hodge's 1985 list of countries.

In the past Jehovah's Witnesses have suffered persecution in South Africa, mostly because of their refusal to salute the flag, sing the national anthem, and above all because of their refusal to do compulsory military service. In recent years, however, the situation has much improved; young male Witnesses who would once have been locked up in military prisons were now allowed to do community service instead when compulsory military service for white males was still in force ${ }^{6}$.

The Jehovah's Witnesses appear to have reached Pretoria around 1925. Our informant stated that when his wife's parents moved to Pretoria in that year, there was already a small group in operation. Today, they have about twenty Kingdom Halls scattered across Pretoria and situated in both the 'white' and 'black' areas. There are two organisational structures for Pretoria, divided not geographically, but on the basis of whether English or Afrikaans is spoken more commonly in the meetings. In total, they claim about 4000 adherents in the Pretoria region, which are served by nine preachers, who serve on a fulltime basis but without remuneration.

Even during the years of apartheid, the Witnesses practised racial integration in their religious activities. Today, they are very active in both Atteridgeville and Mamelodi townships, where their conservative dress code gives the local members a reputation of affluence and respectability. There is also a hall in the coloured area of Eersterus. The Pretoria Central Kingdom Hall is integrated to such an extent that it contains members of 12 different ethnic and national backgrounds. There are also a number of black and Indian elders in the Pretoria region. It can therefore be seen that while the Jehovah's Witnesses do not have significant interaction with other religions on a formal level, they do have an internal pluralism in the one sense that has been the Achilles heel of so many South African religious organisations: the question of race.

\section{Theological tendencies}

All the churches in this group show evidence of theological developments that differentiate them from the Christian mainstream. To be more specific, they show a tendency to highlight certain passages or themes from the Bible that have not been regarded with the same importance by the mainstream.

However, in all these cases their self-image is that of a staunchly Christian, perhaps even

6. Compulsory military service was abolished in South Africa between our field research and the the writing of this article. 
of the most perfectly Christian organisation. Mainstream Christians would disagree, in fact some mainstream Christians might go as far as to deny that one or more of these churches is Christian at all. One might question if it is permissible to use mainstream Christianity as the yardstick, as our classification system clearly does. Here we can only say that our classification system owes more to sociological and historical criteria than to theological ones. Let us therefore commence with the group that shows the least deviations from Christianity as it is generally understood in Pretoria, and work our way from there to the more radically different groups.

The Adventists are a Christian group who regard themselves as being in the Protestant tradition. According to mainstream Christian theologians, their main theological point of difference with other churches lies in their theory of atonement. In Seventh Day Adventist belief, one source writes, atonement was not completed with the crucifixion of Christ. It has yet to be completed and will do so only with the Second Coming (Gerstner 1979: 11). But one of our respondents countered that the actual position is more complex: 'Officially, Adventists believe that Christ has completed His atoning sacrifice (on the cross) and while the atoning sacrifice at Calvary was sufficient and complete, without the resurrection we would have no assurance that Christ had successfully finished His divine mission on Earth"7. Another respondent saw things in a simpler, more direct way; 'I think that historically our church has felt that it had a special message to the world. And that was the second advent of Christ ... Once our church was almost the only one that spoke about the second advent, now all the churches are discussing it.'

Their most visible difference in modern western society is their insistence in celebrating Saturday, rather than Sunday, as their weekly day of rest and worship, but they also use the Old Testament dietary laws as a dietary guideline, and some have even become vegetarians ${ }^{8}$. Abstention from alcohol and tobacco is also advocated, though with varying success (Steyn 1993:19). They practise adult rather than infant baptism and believe that 'foot-washing is an ordinance of Christ and is to be practised at the time of the Lord's Supper' (World Council of Churches 1973:59). A highly critical attitude is maintained towards modern scientific theories of 'Big Bang' cosmology and biological evolution; many, though not all, Adventists hold to a literal interpretation of the Bible, including the book of Genesis (Ministerial Association 1988: ch 6).

We have already seen the emphasis put on the reestablishment of the Apostle ministry by the New Apostolic Church. Another aspect of their theology is their form of millennialism:

We are also unique in our understanding of the day of the first resurrection. No-one else speaks about the first resurrection. They don't even know about it, although it is written in the Bible. Most people think that when Christ returns; then it would be the judgement day, which is absolutely untrue. Because it says in Revelations 20 verse 6, 'Blessed and holy are those who partake in the first resurrection.' For them the second date has no power and they shall reign with Christ a thousand years. And after the thousand years have expired, Satan will be loosened from his prison to try the people who have been taught for

7. See Ministerial Association 1988: 313 \& 115.

8. Bird (1961:16-17) Our research found that the Seventh Day Adventist Reform Movement put far more emphasis on this than the Seventh Day Adventist Church. One member of the latter church stated, for instance, that while he was a vegetarian, this was 'simply for health reasons'. The Reform Movement, however, presented us with a pamphlet called 'Why I am a vegetarian', in which it appears that its stance on vegetarianism is based on Genesis 1:29. 
a thousand years by Christ and his one hundred and forty-four thousand priests, and they will then have to make their decision on judgement day. All who did not partake of the first resurrection will then be judged before God. And then eternity starts.

The Jehovah's Witnesses also maintain a millennialist view, but the most striking difference between them and conventional Christians is the fact that they do not believe in the trinity. This is most obviously expressed in their use of the name 'Jehovah' to denote the deity (Watch Tower Bible and Tract Society of Pennsylvania 1984). They are not the only Christian group in Pretoria that rejects this key doctrine of conventional Christianity: for different reasons, so do the United Pentecostal Church and Die Gemeentes van Christus. The Witnesses regard God as always superior to Jesus, whom they view as a supernatural, yet created being. As one of their publications puts it 'Although in the Bible Jesus is often called the Son of God, no-one in the first century regarded him as God the Son' (Watch Tower Bible and Tract Society of Pennsylvania 1989:16 - our translation). The Witnesses differ from mainstream Christians in many other ways, such as their insistence that Jesus died on a stake rather than on a cross ${ }^{9}$.

Of all the churches discussed in this chapter, it is probably the $L D S$ Church that has made the most sweeping changes to traditional Christian doctrine. If an insistence on the Saturday Sabbath is the hallmark of Adventism, the importance of the post of Apostle that of the' New Apostolic Church and a strict non-trinitarian monotheism that of the Jehovah's Witnesses, the Mormons can be said to give far greater than usual attention to the idea of the 'lost tribes of Israel'. These are described in the Book of Mormon as having migrated to the Americas and formed the pre-Columbian civilisations.

Not only has the LDS produced a 'third Testament' in the Book of Mormon, but it also holds to an unusual, though quite humane, view of the afterlife:

When the body dies the spirit goes to a place that we call the spirit world. The spirit world is divided into two portions, one is called the spirit prison, Jesus Christ referred to that. The other is called the Spirit paradise. Those who have accepted the Gospel of Jesus Christ and who have received the ordinances of baptism and so on go to the Spirit paradise when they die. But there are a lot of good people who, if they heard the Gospel, would go there. So we believe that the people who live in the Spirit paradise are preaching the Gospel to the people in the Spirit prison. The Spirit prison is not quite hell. We believe that hell is only going to appear after this life. You see, when you die there is a partial judgement, but the final judgement is after the thousand years of peace where we believe that there will be peace among all the people, whether they are members of the church or not, and after that the Saviour will come and judge all the people upon the earth according to their work. And then again we don't believe just in a heaven and a hell. We believe that few people are actually going to hell. We call that outer darkness. We believe that God has created different kingdoms of glory. We believe in three kingdoms, the one is of course the Kingdom of Heaven, that is, in the presence of God Himself, we call it the Celestial kingdom. The second kingdom is the Terrestrial kingdom, this is where people go who are good people, but who have not

9. The Witnesses quote Galatians 3:13 and Acts 5:30 to support this. However, it must be noted that they have produced their own Bible translation, the New World version. We are not aware of any scholarly comparison between this and other translations. See Watch Tower Bible and Tract Society of Pennsylvania (1987:13) for a list of biblical references which are seen by the Witnesses as supporting their theological claims. 
accepted the Gospel of Jesus Christ. They certainly do not deserve to live with the wicked one day. Then there is the third kingdom, there we believe all the murderers and the liars will go. It is still a kingdom of glory, but they will not be able to live in the Kingdom of God. First they must recognise Jesus Christ as the saviour of the world. Whereas those in the outer darkness are people that follow Satan, openly and blatantly, and denied Jesus Christ and would crucify Him if they could.

From either a conventional Christian or an academic point of view, a case could be made for regarding Mormonism as a separate, new religious tradition that builds upon Christianity in much the same way that Islam did in the sixth century. But that would negate the LDS Church's self-understanding: not only does it regard itself as Christian, but indeed, it regards itself as the true Christian Church, re-established after the true church's demise in the first century. The same is true of the other churches in this group, to a greater or lesser degree:

The church of Jesus Christ was organised in the beginning of time. We believe that church died out with the Apostles through prosecution and possibly even through unrighteousness on the part of church members. We believe that the church has been restored to what it was in ancient times. (LDS Church)

We have the Apostle ministry which Jesus instituted in the beginning and which was removed from the church, one could say, by all the killing in Roman times. And we believe that there must be Apostles, because without the Apostles we cannot receive the Holy Spirit. (New Apostolic Church)

In the same way, the Adventists and Witnesses would maintain that the establishment of their church was in fact a purification of Christianity from historical accretions, a reestablishment of the true church.

All these churches share a strong interest in eschatology. The Adventists even took their name from this theme (the Second Advent). The biblical book of Revelations was quoted time and again by our informants, though with very different interpretations. This again points to their common origin in the religious fervour of Anglo-American society in the early nineteenth century.

\section{Alternative forms of Christianity and their neighbour religions}

The fact that each of these churches regards itself as a purified Christianity implies that interdenominational dialogue and joint action is a problem for them. As one would expect, it is the Seventh Day Adventist Church that has gone the furthest in this regard; of the churches we investigated, it is the only one that has applied even for observer status at the World Council of Churches. As he put it: 'Historically and traditionally our church is opposed to other churches and they are opposed to us. But we've learned to live together.' Another Adventist put the local situation as follows:

Presently a Reformed church uses our Pretoria Central Church. Before we had our own church buildings in Pretoria East we hired the Methodist Church's building. We had very good relations with them.

The LDS Church too has co-operated with other churches on matters on mutual interest, though more so in the USA than in South Africa. The other churches in this group generally maintain a more isolationist attitude, but few of them were prepared to state unequivocally 
that non-members were irretrievably lost.

I believe that God has more members in his invisible church than in the visible one. We believe that the true Christians are not gathered under the same umbrella. They are all over in different denominations. (Seventh Day Adventist Reform Movement)

Attitudes towards members of non-Christian members were a little more strident, but even here there were thoughtful comments:

I am always amazed at the respect for the word of God among the people. I witness in Laudium and even the Hindus allow you to read the Bible. They have no problem with that. And you get the Muslims, who are a lot more orthodox, of course. They don't find it so easy, but the Koran acknowledges Jesus as a prophet and we have excellent discussions on that basis. (Jehovah's Witnesses)

In many of our interviews and in our attendance at church services, particular criticism was levelled at the 'New Age Movement'. This is rather surprising, considering the low level of representation of this movement in Pretoria.

The respondents of the LDS Church were the most emphatic that 'there are good people in all the religions'. Indeed, one could argue that the Mormons' unusual view of the afterlife, with its many different levels for people of different moral standing and levels of faith, makes it easier for them to accept the existence of other religious traditions. The most conservative group in this regard was the New Apostolic Church. We asked the respondent if a member of a different Christian church could be saved:

According to us, he hasn't got the Holy Spirit, because he does not accept the Apostles of Christ, and because they are not sealed souls, they are baptised with water but not with the Holy Spirit.

\section{Baptism}

Baptism is in fact a very important theme in this group of religious traditions. Most of these groups practice baptism by immersion of adult members, though the age at which 'adulthood' is reached varies from group to group to as low as eight years in the case of the Mormons. Only the respondent from the New Apostolic Church said that 'We normally have children's baptism. ${ }^{10}$ However, the member's soul is not 'sealed' until his or her baptism has been confirmed by a laying on of hands by a living Apostle. This is the 'baptism with the Holy Spirit' and those who have received it will be counted among the 144000 sealed souls of Revelations 7 and 14. It is our understanding that this second baptism is normally performed on adult members in good standing.

The LDS Church conducts the ritual of being baptised by proxy. This is normally conducted on behalf of one's ancestors, who thereby gain the possibility of being saved even after death. A similar ritual is also held by the New Apostolics. The LDS Church also takes the notion of a 'priesthood of all true believers' rather literally. Nearly all adult male Mormons are part of the LDS priesthood, starting with a boy's ordination as deacon at the age of about 12 .

10. Our interview with a black member of the New Apostolic Church showed that this branch of the church tends towards adult baptism, not as a matter of principle, but because it tends to receive new converts rather than just accepting the children of existing members into the church. 


\section{Church discipline and expulsion}

Like other Christian churches, the organisations discussed here invariably have a formalised code of discipline. This may lead eventually to the expulsion of an errant member for offences such as 'denial of faith in the fundamentals of the gospel and in the teachings of the church' or 'immoral and disorderly conduct'. But like most other churches we spoke to, they seem quite reluctant to apply these rulings rigidly. Most of our interviewees stressed the necessity of approaching the person concerned personally and trying to make him change his ways before taking formal action in terms of church law: There is only one way to discipline a person, and that is to teach the person about the wrong things he is doing. Teach him until he changes and he will be forgiven. There is no other discipline besides that. Isolation does not discipline a person, jail does not discipline a person. If someone has made a mistake, he should be preached to and shown his mistakes and once he regrets his action he should be forgiven. (New Apostolic Church)

We don't adapt to the standards of the world, we adapt to the standards that we believe to be proper. For example, sex before marriage is improper. And a person who falls in that category will be disciplined by the church, but in a very confidential manner. In fact, the members will probably not even be aware that a particular person is being disciplined. What would happen if I broke a moral code is that I would probably talk through it with my bishop. If I repented there would probably not be a disciplinary hearing, but if I did not and if I brought the church's name into disrepute, the bishop would select a small council. Only in the case of those who would then decide that they did not want to live according to those moral laws any more would there be excommunication. This would mean that they could still come to church and we would probably still send teachers to their homes, but they may not partake of any of the privileges of the church. They may not pay tithing, or give a talk from the pulpit, or act in the office of the priesthood. (LDS Church)

No, we do not make use of discipline. Perhaps it was used in the beginning here and there, but not in general. We have our ways of dealing with people, we go and see them. We talk to them, but if they don't want to hear, all we can say to them is 'Okay, it is now your responsibility'. We don't ban them from being in the community or anything like that, we just leave it to their own responsibility. (New Apostolic Church)

One might want to argue that such a reluctance to apply formal discipline to the point of expelling members results from the small size of these organisations within the context of Pretoria. If you are already a small church, why risk losing more members? But this would be too simple an explanation. As can be seen elsewhere in this book, even the largest churches are nowadays reluctant to apply stringently the disciplinary codes that remain on their books. This may point to a general liberalisation of society, or to a slow waning of religious influence on society as a whole. But even more important, perhaps, is the fact of pluralism itself. There is no true religious hegemony in Pretoria, even if some churches occupy a more dominant position than others. Expulsion can only truly be a threat if the expelled person has nowhere to go, if there is no other organisation in which he or she can live according to his or her spiritual impulses. The most obvious example would be the medieval church in Europe: one who was excommunicated in those days was truly outside the bounds, not only of society, but also of any possibility of salvation. But in modern, religiously plural society, the person who has been expelled from a given church is almost certain to find another religious 
organisation that is more in line with his or her views. In our opinion, it is not secularisation that has caused churches to decrease their emphasis on strict, by-the-book church discipline, but the fact of religious pluralism, or to put it more concretely, the fact of religious competition for members.

\section{Views and structures}

Even the most fervent sectarian movement eventually matures into a settled, socially acceptable denomination as time passes and the members move up the economic scale. In our opinion, and in the context of Pretoria, the Seventh Day Adventist Church has moved the furthest in this direction: in Pretoria today, few would even lift an eyebrow if they were told that a particular person was an Adventist. The Jehovah's Witnesses are also well accepted by Pretoria. This might be due to just how familiar the sight of their 'witnessing' door-to-door has become over the year. The other groups are slightly less well received by Pretoria generally, but none of these groups informed us of any active opposition to their activities from either the authorities or the people of Pretoria.

In white Pretoria, at least, these groups now have a solidly middle-class following, although most of these churches can be shown to have had distinctly proletarian origins. Among our interviewees, those who were not full-time preachers included an opera singer, a psychiatrist and a university professor. If these churches are not quite part of either the 'old' or the 'new' South African political power structures, they are nevertheless comfortably ensconced in the middle echelons of society. This is not true, however, of the Seventh Day Adventist Reform Movement, whose pastor freely admitted to us that his congregation consisted largely of 'poor people'. But this makes perfect sense when one considers that it is itself a relatively recent sectarian breakaway from the Seventh Day Adventist Church. Little information is available on the black members of these churches, but informally, the indications are that they too are somewhat above average on the economic scale, compared to the rest of their community.

Even more striking than the theological similarities between these movements are the similarities between them in the way their churches are structured and in the way they regard the world outside the church. The important themes here are hierarchy, uniformity and conservatism. These churches are generally arranged in a highly organised, even hierarchical structure.

The highly structured nature of some of these churches can be seen in the procedures we had to follow in order to obtain interviews with informants from these organisations. In the case of the New Apostolic Church, although one of the persons we intended to interview was of high rank in the church hierarchy, we first needed to obtain permission from the church's central office. The Mormons would not let us speak to local representatives, but sent us a delegation from the Johannesburg headquarters, while the Jehovah's Witnesses likewise sent a delegation, albeit one composed of members in charge of the entire Pretoria district. While these restrictions did not hinder the progress of research, it does point to their highly structured level of internal organisation and to a certain reluctance on the part of these churches to impart information to outsiders on an unrestricted basis. To be fair, it must be stated that we encountered similar problems with a few religious organisations that do not fall into this group: these included Christian Science, the School of Truth, the Pretoria Hindu Seva Samaj and the Zion Christian Church.

The two Adventist churches are well organised, though not more hierarchically than many 
mainstream Christian churches. The Headquarters of the Seventh Day Adventist Church is in Washington DC and that of the Reform Movement in the American state of Virginia.

The New Apostolic Church and LDS Church maintain well-defined hierarchies, which culminate in the Chief Apostle in Zurich and the Prophet in Salt Lake City, respectively. The chain of command is pyramidical in structure, though our impression is that the LDS Church is somewhat less authoritarian than the New Apostolic Church.

The Jehovah's Witnesses are not organised in quite as hierarchical a fashion, but they too operate a very efficient organisation centred on the world headquarters in New York. In their case, the trend towards hierarchy and uniformity is expressed in a different way: at every service, in every Kingdom Hall on the planet, almost all Witnesses will be participating in the same programme, which will have been distributed in a variety of languages from the world headquarters ${ }^{11}$. Respondents suggested that this unity of worship bound them more closely together to the international community of Witnesses. This continuity with the worldwide church was considered of the utmost importance.

The Jehovah's Witnesses and the New Apostolic Church were the only two religious organisations of any size in Pretoria whose spokespersons completely rejected the idea that a minister of religion might require some kind of formal training. Many smaller and even medium-sized churches cannot afford to maintain a seminary, of course, but interviewees from these churches would typically admit that formal education in the ministry was, in principle, a desirable thing. The Witnesses and New Apostolics, however, not only did not conduct such training on a formal level, but rejected the very notion. In these churches, spiritual growth and advancement in the church structures comes about as the result of a mixture of practical experience and divine inspiration. To some extent, this is also true of the LDS Church, but in that case it is less a case of rejecting formal education than it is a case of this training being given in a diffuse way within local church structures. In Utah, of course, the Mormons have founded Brigham Young University. The two Adventist churches train their pastors in a more conventional manner.

Despite the individual social requirements made by these churches that often conflict with societal norms, such as the Adventist's insistence on celebrating the Sabbath on Saturday or the Witnesses' refusal to take oaths, sing the national anthem and salute the flag, they generally fall into the conservative end of the social spectrum ${ }^{12}$. But unlike some other conservative socio-religious groups, they are relatively untainted by the institutionalised racism of recent South African history. If they have not led the fight against apartheid, neither have they provided it with theological justification. Although they have all maintained separate congregations, mainly along linguistic lines, all our informants stated that a black member would be welcome in a church in a white area, and vice versa. The level of solidarity between black and white members was high, especially from the black perspective: a black member of the New Apostolic Church was asked how he related to the white branch of the church. He answered 'We just relate as members of one church.' Similarly, a black Jehovah's Witness simply replied

11. This way of ensuring religious uniformity is also used in Christian Science (See part II).

12. Within this conservative end of the spectrum, of course, some are perceived to be more conservative or more liberal than others. This is what the speaker from the Seventh Day Adventist Reform Movement had to say, for instance, about the Seventh Day Adventist Church: 'They are, in reality, quite liberal today ... In the beginning, among the Adventists, they were married for life; only later on did they adopt divorce and remarriage.' 
'We are one'. From our investigations, we believe that the same is true of the other churches in this group.

Evidence of conservatism and uniformity is also shown by the insistence by the same two black informants that members should sit and stand quietly during services, without the ecstatic dancing that typifies services at the Independent churches and nowadays also at many predominantly black congregations of the mainline churches: 'We just stand up and sing, without shaking'.

The conservatism of this group is nowhere more evident than in their treatment of the issue of female office-bearers. All of them have established structures in which female members can fulfil certain functions, usually in welfare or support positions. However, none allow women to become fulltime, professional preachers or to advance to the highest positions in the church hierarchy. The Seventh Day Adventist Church does allow women to become elders, but as yet 'only a few churches have appointed women as elders.' The Mormons and New Apostolics explained that while they regarded men and women as equal before God, there was nevertheless a difference between the sexes. This divinely-ordained difference prohibited women from preaching. The case of the Jehovah's Witnesses is somewhat different. They do not have a paid ministry, but 'All of Jehovah's Witnesses who are dedicated and baptised are ministers', and this would include the female members. The international governing body, on the other hand, consists exclusively of men (Watch Tower Bible and Tract Society of Pennsylvania 1986: 22, 26).

One area where some of these churches have in the past come into conflict with the South African government has been the issue of compulsory military service. The Jehovah's Witnesses have long endorsed a policy of conscientious objection, and have suffered persecution for it both in South Africa and elsewhere. The Seventh Day Adventist Reform Movement takes a similar view. The Seventh Day Adventist Church also has an official policy of non-combatancy, that is, cooperation with the military in a non-fighting role, but one respondent said that in practice 'we leave it open to the individual young man whether or not he wants to take up arms.' The LDS Church and the New Apostolic Church had no objections to compulsory military service, with certain provisions:

We can only say that we must be obedient to the government. As long as the government doesn't go against the law of God. Then we are obedient. (New Apostolic Church)

We teach that you should sustain the government of the land as far as possible, but that does not mean that you should sustain an unrighteous government. (LDS Church)

Even the black members of these churches tended to acquiesce in the political situation before 1994:

We try to attract people back to God and to respect the government. The apartheid government was not nice but it was a government. People should realise that a government only exists because it is God's will. That government was not good because it separated and segregated people of God from each other. But I am not going to hate those people who were in that government because they too were people of God. (New Apostolic Church) 


\section{Mission}

Missionary activity has historically been the very lifeblood of these movements, but there are differences in the way in which they approach it. The Jehovah's Witnesses are perhaps the best known for the door-to-door 'witnessing' that has given them their name. In Pretoria, as elsewhere in the world, they continue to perform this duty tirelessly. What is perhaps not as well known, is the extent to which such activity is the result of conscious planning and organisation. A black Witness told us that:

Each member is given a card. This card is kept by the local secretary. He is the one who investigates our work. You have to write on your card how many people you have visited and how many books you have sold. Right now I have made 80 visits this month, but I need another 10 to reach the target which the elders have set for me.

The Mormons also have fulltime missionaries engaged in such work, but not quite on the same scale in this city. The other churches have more modest evangelisation programmes, which work largely on a person-to-person basis. In some cases these have also expanded to include use of radio and of public gatherings that combine evangelisation with entertainment and 'boeresport' types of activity. They also reported that they were growing strongly, but their expansion in white Pretoria seems to have peaked. The greatest growth potential in Pretoria for all of them now seems to lie in the black townships. The new Mormon chapel in Atteridgeville and the strong black contingent at a Witnesses' rally at the Pretoria Showgrounds at the end of 1994, which one of us attended, attest to this.

Most of our respondents in this group were cautiously optimistic about the political changes in South Africa. The white respondents, in particular, praised the actions of then-State President FW De Klerk. But we interviewed most of them before the 1994 general elections, and many expressed their concern at the level of political violence in the country. Some respondents linked this directly to their eschatological beliefs:

If you look around, it is not only South Africa that is in a state of tumult. Countries everywhere have this problem and I believe that this is a sign of the fulfilment of the prophecies. (Seventh Day Adventist Reform Movement)

I personally think that the President (De Klerk) is doing his utmost best to work these things out. And we hope that he succeeds, because it will be to everybody's advantage to have peace in the region. But we also know that the world is going downhill, not just in South Africa but all over the world. If you look at the news today there are riots everywhere, dissent, dissatisfaction ... Governments no longer have any say, the bosses no longer have any say, because we are living in the end time period, where the will of the people rules. But we know that this is a sign of the times and the Lord will come before it becomes too bad. (New Apostolic Church)

The respondents from the LDS Church too did not perceive the political changes as threatening to their church, though they expressed their conviction that ultimately the wellbeing of the country depended on divine intervention and the behaviour of people in general that would save the country, rather than the dealings of politicians.. 


\section{The 19th Century Alternatives in Pretoria}

All the churches discussed in this chapter indicated that they had found a congenial home in Pretoria. None reported any overt religious persecution peculiar to the city. In fact, recent political changes seem to have given them a new confidence; one respondent, who worked in a hospital, stated about some of his patients that, "Nowadays if one of them is Dutch Reformed, he is almost ashamed to say that he is in the Dutch Reformed Church. I think we have a role to play in the change in South Africa. That is why we are now regrouping and reorganising.' There seems to be an unspoken belief among these churches that their position in the new South Africa will improve, that the very fact that they cannot be linked directly to the past regime will work in their favour.

Those churches that are still predominantly English-speaking have found this to be a hindrance to their expansion in the city, where the predominant languages are Afrikaans and Northern Sotho, but all have instituted ways and means to try and overcome this problem. The city and its inhabitants came in for criticism on a number of points relating to its ethos as a national capital:

pride is the worst form of pride. And I can tell you that it is quite strong here in Pretoria. They are very proud of their own faith and they form a very closed circle. When you are so well off and comfortable you feel that you do not need anything, not even God.' Why should you need to go to heaven when you have your own heaven here? Most people here in Pretoria have never known what it means to be hungry. I have never met people so proud of their religious positions and I have been all over the world. (Seventh Day Adventist Reform Movement)

\section{Conclusion}

Our main reason for grouping these churches together was a historical one. They share a common origin in the first half of the nineteenth century and all but one originated in America, and that one started in the religiously closely related environment of England. To a large extent they still display the conservative ethos of that era.

There are great theological differences between them. But while they do not share an overall theological framework, they do show a common tendency to emphasise certain biblical verses and themes that are generally regarded as less important by mainstream Christianity and to raise these to their church's very reason for existence.

Although we do not agree with the theological positions of any of these churches, we did develop an admiration for the way they doggedly keep on going in the face of social disapproval, if not outright oppression. In Pretoria, the social pressure to join a mainstream church has historically been immense. In a way, this pressure has been focused more strongly on members of alternative Christian movements than on atheists and members of non-Christian religions. After all, the Witnesses, Mormons and others were already much closer to a conventional Christian point of view, so why not just join a conventional church? To be in a minority is difficult at the best of times, but to be in a minority so close to the majority position is doubly so. In the face of this kind of pressure, these churches have not only maintained their identity for over half a century, they have steadily expanded throughout the Pretoria region. Each of these churches would no doubt see this as evidence for their divine calling. We prefer to see it as evidence of the courage and determination of their members, and we commend them for it. 
We do not expect that any one of these churches will feel comfortable with the way we have classified them. But we do feel that our typology is not unreasonable; these churches do have more in common than just history. In Pretoria, they collectively form a conservative Christian-oriented alternative to the main Afrikaans and English churches. We cannot tell how large a religious 'market' there still is for this form of religious practice, particularly at a time when the city and the country as a whole seem to be slowly moving in the opposite direction, religiously and otherwise. But perhaps the liberalisation of South Africa will produce a new generation of people disenchanted with secular society and conventional religious practice. These people may then be receptive to the message of these churches. 


\section{BIBLIOGRAPHY}

Gerstner, JH 1979. The teachings of Seventh Day Adventism. Grand Rapids, MI: Baker. Hewat, EGK 1967. Meeting Jehovah's Witnesses. Edinburgh: Saint Andrew. Hodges, T 1985. Jehovah's Witnesses in Africa. London: Minority Rights Group.

New Apostolic Church 1988. Chronicle. The New Apostolic Church in Pretoria 1911-1988. Bedfordview: New Apostolic Church (Transvaal).

South African Statistics 1992. Pretoria: Government Printers.

Steyn, FG 1993. Consultant's report to the Sunnyside SDA church. Unpublished research report: Pretoria, South Africa.

Watch Tower Bible and Tract Society of Pennsylvania 1984. The Divine Name that will endure forever. [sl].

Watch Tower Bible and Tract Society of Pennsylvania 1986. Jehovah's Witnesses. Unitedly doing God's will worldwide. [sl].

Watch Tower Bible and Tract Society of Pennsylvania 1987. Jehovah se Getuies in die twintigste eeu. [sl].

Watch Tower Bible and Tract Society of Pennsylvania 1989. Moet jy aan die Drie-eenheid glo?. [sl]

World Council of Churches. 1973. So much in common. Documents of interest in the conversation between the World Council of Churches and the Seventh Day Adventist Church. Geneva: World Council of Churches.

\section{OTHER SOURCES}

Ball, BW 1981. The English connection. The Puritan roots of Seventh Day Adventist belief. Cambridge: James Clarke.

Bird, HS 1961. Theology of Seventh Day Adventism. Grand Rapids, MI: Wm. B Eerdmans.

Church of Jesus Christ of Latter-Day Saints 1989 Die Boek van Mormon. Salt Lake City: Church of Jesus Christ of Latter-Day Saints.

Damsteegt, PG 1977. Foundations of the Seventh Day Adventist message and mission. Grand Rapids, MI: Wm. B Eerdmans.

Douty, NF. [sa] Another look at Seventh Day Adventism. Grand Rapids, MI: Baker.

Duncan, BR 1969. The New Apostolic Church: Truth or error? [sl]: Sunday School Centre Publishers.

Herndon, B 1979. The seventh day. The story of Seventh Day Adventism. Westport, CONN: Greenwood.

Hoekema, AA 1973. Jehovah's Witnesses. Exeter: Paternoster Press.

Hoekema, AA 1973. Seventh Day Adventism. Exeter: Paternoster.

Ministerial Association 1988. What Seventh Day Adventists believe: a biblical exposition of 27 fundamental doctrines. Washington, DC: Ministerial Association, General Conference of Seventh Day Adventists.

Molokatsie, C 1994. Mormons in the townships. Challenge: church and people. no 24 August 1994. pp 22-23.

Neufeld, DF \& Neuffer, J (eds) 1976. Seventh Day Adventist encyclopaedia (revised edition). 
Washington, DC: Review and Herald Publishing Association.

New Apostolic Church 1985. Neuapostolische Kirche/New Apostolic Church/Eglise Neo Apostoliquel Iglesia Nueva Apostolica. Zürich: New Apostolic Church.

Rogerson, A 1969. Millions now living will never die. A study of Jehovah's Witnesses. London: Constable.

Swanepoel, LF 1972. The origin and early history of the Seventh Day Adventist Church in South Africa, 1886-1920. Unpublished MA dissertation, University of South Africa.

\section{Other works in the series 'RELIGION IN PRETORIA'}

Clasquin, M \& Molobi, VS 1994. Directory of religious organisations in the Greater Pretoria area. Pretoria: C. B. Powell Bible Centre.

Clasquin, M 1995. Researching a city's faiths - methodological notes from the coalface. Religion \& theology 2:3 pp 256-273.

Clasquin, M 1997. The lotus in the lion's den: Hinduism in Pretoria. Journal for the study of religion: 10/1, March 1997.

Clasquin, M Alternative religion in Pretoria, Part II: East comes south. Scriptura: in press.

Clasquin, M The Jewish experience of an Afrikaner city. Religion \& theology: in process.

Clasquin, M The prophet's children in Pretoria: Islam in the heart of Afrikanerdom. Article in preparation.

Krüger, JS Sweeping whirlwinds: religion in Pretoria. Book in preparation. 